\title{
A study on Environmental Disclosure in Central Kerala
}

\author{
Remya S ${ }^{1}$, Andrea Varghese ${ }^{2}$ \\ ${ }^{1}$ Assistant Professor \& Part time Research Scholar, St Joseph's College Autonomous, Irinjalakuda \\ ${ }^{2}$ Adhoc faculty, St Joseph's College(Autonomous), Irinjalakuda
}

\begin{abstract}
Accounting word comes from business or commercial activity i.e., trading, buying or selling. Environment refers all surroundings of a living organism, non-living organism and natural forces which provide the conditions for development and growth as well as of danger and damage. Environment of business affects the internal or external factors which influence the business. But due to business activities the environment of the earth is degrading and as result the new green accounting practices has emerged. Companies are now being pressurized to disclose their environment performances in their annual or sustainability reporting. This paper seeks to analyze the disclosure of the companies in this regard. For this purpose, a sample of 179 respondents of 10 companies' manager, accountants and CAs were selected to present their views and the same has analyzed. Those ten companies were: Scientific Livestock Farms India Pvt Ltd, Kizhakkambalam, Relational Farms and Animal Husbandry PvT. Ltd., Edappally, Edassery Enterprises Private Limited, Thevara, Kathayee Cotton Mills Ltd, Perumbavoor, Kitex Garments Limited, Ernakulam, GTN Textiles Limited, Aluva, Natural Fibre Products Consortium Private Limited, Palarivattom, Our own Carry Bags Pvt. Ltd., Ollur, Trichur, Saw Mills and Industries Limited, Kokkala Thrissur, Patel Babulal Pranlal Timber Products Private Limited, Shanmugam Road, Ernakulam. The result revealed that respondents have exhibited a fair amount of agreement on need of Energy Minimization as significant positive gap has been observed. Further, out of 25 variables 9 variables i.e., Comp_ER_4, Comp_ER_2, Comp_ER_5, Comp_ER_21, Comp_ER_20, Comp_ER_24, Comp_ER_17, Comp_ER_8 and Comp_ER_9 explains the companies practice/working influence their environmental disclosure
\end{abstract}

Keywords: Financial Accounting, Cost Accounting, Management Accounting, Tax Accounting.

\section{INTRODUCTION}

Organizations in their early days referred traditional method of accounting like Financial Accounting, Cost Accounting, Management Accounting, and Tax Accounting but now all the organizations need modern accounting system which affects the company's Profitability. All the organizations want to analyze Non-monetary transactions also because it increases the company's profitability and give complete information to investors and shareholders. Non-monetary transactions include CSR activities i.e. Education Programme, Environmental sustainability, Protection of national heritage, Rural development projects, slum area development etc. CSR activities are mandatory for all the Organizations; this activity is not engage in normal course of business so, it's important to find out CSR expenditure. Environmental accounting and sustainability reporting both are important for company's growth and development. It provides detailed information to shareholders and also increases GDP and NNP.

\section{GREEN ACCOUNTING}

Green Accounting is an important tool for modern accounting system which played an important role to understand the natural environment of the economy. Green accounting sometimes referred as Environmental accounting, Natural capital Accounting, Resource accounting and integrated economic and Environmental accounting. Green accounting calculate the cost and revenue of environment activities and also helpful for decision making of environment resources to economic well-being. The environmental dimension of sustainability reporting concerns an organization's impacts on living and non-living natural systems, including ecosystems, land, air, and water. Environmental Indicators cover performance related to inputs (e.g., material, energy, water) and outputs (e.g., emissions, effluents, waste). In addition, they cover performance related to biodiversity, environmental compliance, and other relevant information such as environmental expenditure and the impacts of products and services.

Businesses use three generally accepted methods to implement environment accounting: financial accounting, managerial accounting and national income accounting. Financial accounting is the process of preparing financial reports, such as earning statements, for presentation to investors, lenders, governing bodies and other members of the public. In this instance, environmental accounting estimates are presented as part of the financial accounting reports. Managerial accounting is used solely for internal decision making. In this capacity, department heads use environmental accounting 


\section{International Advanced Research Journal in Science, Engineering and Technology \\ Impact Factor 7.105 Vol. 9, Issue 1, January 2022 \\ DOI: 10.17148/IARJSET.2022.9156}

to collect dataused by senior management to make business-critical decisions, such as those surrounding procurement. Alternatively, environmental accounting is used by government agencies to calculate the nation's gross domestic product and how business decisions affect the country's economic wellbeing. Go-Green, Green awareness are continues grow in business, Organizations and Society, Environment accounting measure the impact of the economy has on environment and how it contributes to society or economy by using the accounting principles/standards of national accounts. Green accounting, green procurement activities and research and development played a vital role for future corporate sustainability. Environment accounting is a part of Social Reporting, Corporate Social Responsibility and Sustainable reporting.

\section{REVIEWS OF LITERATURE}

Gupta (2008) studied a top 50 company's annual report to analysis their environmental disclosure practices. In this study an index of environmental disclosure listing 23 item of information has been used to find out the actual disclosure practices in these companies. He found in our study the company's are aware about the fact of environmental issues which the effect the business and industries in the future. Despite this awareness the companies do not have a proper environment accounting system to determine the environment related cost, benefits, assets and liabilities. In India companies fail to provide adequate disclosure of the environment. He concludes that there is a low level of environmental accounting and reporting activity in India.

Anita Jose and Shang -Mei Lee (2006) investigate the environmental management policies and practices of the 200 largest corporation in the world. They found out some interesting facts regarding the disclosure practices of environmental reporting. They said $60 \%$ of the world largest companies have environmental policies and $41 \%$ of company disclosure the need of Environment management system. In this study they found US 63.22\%, UK 83.33\% Japan 75\% and Germany $73.68 \%$ are disclosed.

Jose M.Moneva, Pablo Archel and Carmen Correa (2006) attempted to explore the strong / weak sustainability concept. The study aimed to look at sustainability development approach with in the GRI guidelines and what are its impact on corporate reporting and what conception of sustainable development is to constructed and diffused. In the first phase of the study that the understanding the concepts of sustainable development and that interaction changing the concept have been companies were adopting the G.R.I guidelines to prepare their sustainability reports but at the same time the SD assumptions are low. In the second phase of study/after building the G.R.I guidelines they worked for stronger sustainable reporting system. According to consequences circumstances GRI guidelines are used as a new tool of management decisions and actions.

Dangwal \& Sharma (2014) have identified the extent of environment disclosure of selected Indian Pharmaceutical Companies and to rank them according to their extent of environmental disclosurein their annual and sustainability reports. They selected nine pharmaceutical companies from the universe of top 100 Indian companies by their market capitalization. In this study they used the content analysis technique to examine disclosures in annual reports. They found that all the companies are voluntary disclosing the important parameter of environment like, energy, water, emission, waste and management. Most of the companies avoid disclosing the sustainability reports separately along with annual reports. They found that the level of environmental disclosure score in the reports of selected companies was not very encouraging. There were lots of variations in the environment disclosure scores between selected pharmaceutical companies. The overall mean disclosure score of all the companies was only 35.85 which shows the extent of environmental disclosure of selected companies was very low.

Nasiri \& Raju (2014) in their research paper tried to compare the environmental practices of Indian \& Iranian companies by content analysis methods. They randomly selected companies from Tehran Stock Exchange Iran in five different sectors (Automobile, oil/gas /petroleum \& chemical, food, cement, metal) and also 60 companies were randomly selected from Mumbai stock exchange India. The environmental check list was constructed for seven dependent variables and these dependent variables consist 22 sub variable data have been analyzed using SPSS. They found that mean score of current environmental practices in Indian \& Iran is significantly different. The mean score of current environmental practices is 0.42 which is significantly higher than Iran whose mean score of current environment practices is 0.32 in this context null hypothesis is rejected and alternate hypothesis is accepted. From the analysis Indian companies are reporting better than Iranian companies.

Eugenio D' Amico, Daniela Coluccia, Stefano Fontana \& Silvia Solimene (2014) studied thefactors that influence the environmental disclosures of Italian listed companies. He also aimed to verify the effects produced by the introduction of specific legislation on environment disclosures. They analyze the determinants of Voluntary Environmental Disclosures i.e. Firm Size, Business Industry, Economic performance, Financial Situation, Firm Age, Foreign Market, Public Shareholders, Company Ownership, Audit, Legislation etc. For testing the hypothesis they select a 170 sample companies listed on the Italian Stock Exchange in Milan on the dates of $31^{\text {st }}$ December $2006 \& 31^{\text {st }}$ December 2009. To test the hypothesis they made econometric model and use a multivariate analysis. They found a negativerelationship between the presence of minority shareholders, large auditors and listing the company on foreign markets and 


\section{International Advanced Research Journal in Science, Engineering and Technology \\ Impact Factor $7.105 \div$ Vol. 9, Issue 1, January 2022 \\ DOI: 10.17148/IARJSET.2022.9156}

environmental disclosures. In this descriptive statistics shows the dissemination of environmental information in Italy is still insufficient comparisons required by the guidelines of GRI and ESG. They found results an average quantitative environmental disclosure of $7 \%$ and $4.9 \%$ of qualitative disclosures of Italian companies.

Norhasimah, Bahari, Adnan, Qamarul, Kamal \& Ali (2015) examined the relationship between environmental disclosures with the firm's financial performance of the Malaysian listed companies. In this study researcher took 100 sample companies of Market capitalization in Malaysia for the year 2011. The Study dependant variable is financial performance of the firm i.e. ROA, ROE, EPS \& Profit Margin and the independent variables are Environmental Disclosure Contents. EnvironmentalIndex tested by using Kolmogorov Smirnov testing and they found that the data is not normally distributed. For testing the hypothesis Spearman Correlation technique was used and the result found that there was significant relationship between total environmental disclosure and profit margin. Therefore the hypotheses were accepted. However the findings for other three variables which are ROA, ROE \& EPS showed no significant relationship between total environmental disclosures. The overall analysis shows mixed results between the existences of the environmental disclosures practices in Malaysia and financial performance. The developing of environmental accounting is still ongoing debate at National and International level. There is no such regulation and requirement for the companies in Malaysia to disclose the environmental sustainability.

Aaron, Mcmillan and Cline (2012) examined the investor reaction to signals of Environmental Management Reputation. In this study researcher select a sample top 100 firms and the bottom 100 firmson Newsweek Green Ranking from 2009. The study wants to found out the favorable recognition for environment management has positive impact on the firm stock price as well as unfavorable recognition has a negative impact on firm stock price. They sought to provide a comprehensive examination of the market reaction to the firm identifies at the best and the worst Environment Management Reputation. Thefirst hypothesized firm would enjoy a positive impact on share price in the short term and second hypothesized firm would suffer a negative impact on share price in short term.

Rahman, Rasid and Basiruddin (2014) examined carbon reporting practices of Malaysian companies. They investigate the relationship between carbon performance, carbon reporting and firm performance. They randomly selected a sample from manufacturing companies listed on the main board ofBursa Malaysia covering the financial period of 2007 to 2012. Data will be extracted through content analysis method from selected companies reporting. Carbon reporting can be found in annual report, environment report and companies websites. Carbon reporting index was develop to study or analyze thecarbon reporting. The index measures the carbon information in terms of its breadth, depth and the reliability of information. The formations of reporting index were consistent with the concept of accountability. This study made a significant contribution to carbon reporting literature by examining the influence of internal organizational factors on carbon reporting. This study also explored the relationship between carbon performance, carbon reporting \& firm performance as well as moderating effect of corporate governance quality on the relationship between carbon reporting practices and firm performance.

Malik \& Mittal (2015) reported a study of green accounting Practices in India. They found that environment accounting was in preliminary stage in India and whatever shows in the accounts in this regard is more or less compliance of relevant rules and regulations in the act. In India people were not aware towards environmental safety; development of accounting was little bit doubtful. In India companies prepared only an environment policy and also mention the details of environmental aspects inannual statement. For sustainable development country must have well defined environment policy as well as proper accounting procedure.

Makori and Jagongo (2013) investigated that there is significant relationship between Environmental Accounting versus Return on Capital Employed (ROCE), Net Profit Margin (NPM), Dividend per Share (DPS) \& Earning per Share (EPS). In this study data were collected from annual reports of 14 randomly selected companies from Bombay Stock Exchange in India. The study had both dependant and independent variables. The dependant variables were amount spent on environmental protection and independent variables were ROCE, NPM, DPS, and EPS. These data and variables were analyzed by using multiple regression analysis through the use of econometric model. These analysis shows the result that all the variables except ROCE \& EPS shows the positive relationship i.e. Environmental Accounting had a positive relationship between NPM and DPS and negative relationship between ROCE \& NPM.

Debnath, Bose and Dhalla (2014) conducted an exploratory study with the aim of understanding and emerging trends of environmental performance. They also want to know about the level of environmental performance and develop ecoefficiency to connect micro to macro level. In this study they selected 16 samples of Indian Companies from GRI portal. They found that Indian organization started GRI reporting from 2001-2005 but they did not see any increment of the number of reporting companies. The maximum participation was found from 2007-2010. Indian companies used G3 reporting level during this period. G3 level of reporting was the latest format applicable which was now improved to G4 standards. They also found the multiple eco-efficiency measures seems to suggest decreasing trend in resource usage during this period towards other improvements which could support and further sustainability derives in these organizations. In addition, the concept of eco-intensity changed index is advanced to develop Sectoral profile by aggregating sector wise environmental performances. 


\section{International Advanced Research Journal in Science, Engineering and Technology \\ Impact Factor $7.105 \div$ Vol. 9, Issue 1, January 2022 \\ DOI: 10.17148/IARJSET.2022.9156 \\ RESEARCH OBJECTIVES}

- $\quad$ To analyze the current practices of green accounting and reporting practices for corporate sustainability

- $\quad$ To find out major variables of environmental reporting by companies

\section{RESEARCH METHODOLOGY}

- $\quad$ Sources of Data Collection: There are two methods for collecting data i.e. Primary sources of data collection which were collected by researcher by using Questionnaire.

- $\quad$ Sample Size: 10 companies from Central Kerala were selected for the current study. Companies were - (1) Scientific Livestock Farms India Pvt Ltd, Kizhakkambalam, (2) Relational Farms and Animal Husbandry Pv T. Ltd., Edappally, (3) Edassery Enterprises Private Limited, Thevara, (4) Kathayee Cotton Mills Ltd, Perumbavoor, (5) Kitex Garments Limited, Ernakulam, (6) GTN Textiles Limited, Aluva, (7) Natural Fibre Products Consortium Private Limited, Palarivattom, (8) Ourown Carry Bags Pvt. Ltd., Ollur, Trichur, (9) Saw Mills and Industries Limited, Kokkala Thrissur, (10) Patel Babulal Pranlal Timber Products Private Limited, Shanmugam Road, Ernakulam

- Data Analysis Method: In this study primary data were collected by Questionnaire method. As per the objectives of the study analysis was done by using SPSS software by using one samplet and multiple regression method.

\section{DATA ANALYSIS}

For presenting the sample demographics the table and diagram is presented. First the companies from which the data were collected is shown in table-1. As under:

\begin{tabular}{|l|l|l|l|l|l|}
\hline Occupation - wise distribution & \multicolumn{2}{l|}{ Designation } \\
\hline & Frequency & Percent & & Frequency & Percent \\
\hline Employed (Private / Govt) & 82 & 45.8 & CA / Accountant & 63 & 35.8 \\
\hline Business & 39 & 21.8 & Manager & 57 & 31.2 \\
\hline Practitioner & 58 & 32.4 & CEO/Promoter & 25 & 14.0 \\
\hline Age & 89 & 49.7 & Qualification & & \\
\hline Up to 35 years & 46 & 25.7 & Professional & 84 & 46.9 \\
\hline $35-45$ years & 44 & 24.6 & & & \\
\hline 45 and above & & & & \\
\hline
\end{tabular}

The above table revealed that the maximum respondents were working in different companies but also involved Professionals of 19 percent; (45.8\%) were Employed (Private / Govt.) followed by practitioner (32.4\%) and business $(21.8 \%)$; maximum respondents $(49.7 \%)$ were of the age of up to 35 years followed by $35-45$ (25.7\%) close to 45 and above year of age $(24.6 \%)$; further respondents $(53.1 \%)$ were qualified up to Masters level close to Professionals (46.9 $\%)$.

\section{Hypothesis Testing}

As per the objective of the study to analyze the current practices of green accounting and reporting practices for corporate sustainability the perception of Top managers, Financial Managers, Financial Consultants, Finance executives, Professional including CA, CS \& ICWAI were taken and totest the differences in the perception for the major variables to be considered for Company's EnvironmentProgramme following hypothesis has been tested:

Hypothesis 1 (null): There is no difference in the respondent's perception opinion regarding major variables to be considered for green accounting and reporting of companies.

To test the above hypothesis the views of the respondents were gathered on the basis of the rank given by the respondent. To analyse the same one sample t test were applied with SPSS-19 software and the results are listed in table- 2 as under: Table 2: One sample t Test

\begin{tabular}{|l|l|l|l|l|}
\hline \multicolumn{1}{|c|}{$\begin{array}{c}\text { A. One-Sample } \\
\text { Statistics }\end{array}$} & N & Mean & Std. Deviation & Std. Error Mean \\
\hline Energy_Minimization & 179 & 1.9441 & 1.44066 & .10768 \\
\hline Waste_Minimization & 179 & 2.6201 & 1.21361 & .09071 \\
\hline Water_Management & 179 & 2.5363 & 1.22821 & .09180 \\
\hline Sustainability_Procurement & 179 & 2.6145 & 1.11275 & .08317 \\
\hline Recycle & 179 & 2.3799 & 1.16640 & .08718 \\
\hline Air_Quality & 179 & 2.4022 & 1.09913 & .08215 \\
\hline
\end{tabular}




\section{International Advanced Research Journal in Science, Engineering and Technology \\ Impact Factor $7.105 \div$ Vol. 9, Issue 1, January 2022 \\ DOI: $10.17148 /$ IARJSET.2022.9156}

\begin{tabular}{|c|c|c|c|c|c|c|}
\hline \multicolumn{7}{|l|}{ B. One-Sample Test } \\
\hline & \multicolumn{6}{|c|}{ Test Value $=2.5$} \\
\hline & \multirow[t]{2}{*}{$\mathrm{T}$} & \multirow[t]{2}{*}{ df } & \multirow[t]{2}{*}{ Sig. (2-tailed) } & \multirow[t]{2}{*}{ Mean difference } & \multicolumn{2}{|c|}{$\begin{array}{l}95 \% \text { Confidence Interval } \\
\text { of the Difference }\end{array}$} \\
\hline & & & & & Lower & Upper \\
\hline Energy_Minimization & -5.162 & 178 & .000 & -.55587 & -.7684 & -.3434 \\
\hline Waste_Minimization & 1.324 & 178 & .187 & .12011 & -.0589 & .2991 \\
\hline Water_Management & .396 & 178 & .693 & .03631 & -.1448 & .2175 \\
\hline Sustainability_Procurement & 1.377 & 178 & .170 & .11453 & -.0496 & .2787 \\
\hline Recycle & -1.378 & 178 & .170 & -.12011 & -.2922 & .0519 \\
\hline Air_Quality & -1.190 & 178 & .236 & -.09777 & -.2599 & .0644 \\
\hline
\end{tabular}

The output of the 'one sample $t$ test' in the table 2, reveals that significant gap exists betweenthe hypothesized test value with the calculated sample statistics for Energy Minimization ( $\mathrm{t}=-5.162$ at $\mathrm{p}=0.000<0.05)$ at $5 \%$ level of significance. The respondents have exhibited a fair amount of agreement on need of Energy Minimization as it has given first rank (minimum mean). And a significant positive gap hasbeen observed as (Mean difference $=4.4000$ ). Hence it reveals that the responses are in favour that thereis a need of focusing the Energy Minimization as a green accounting and reporting practice of companies. As per the objective (to measure the significance of components of environmental reporting by companies) the agreement of the respondents related with the various variables are tested with the broader hypothesis. The perception of the stakeholders was sought in relation to significance of components used in disclosure. The following hypothesis has been tested:

Hypothesis 2 (null): All components used for environmental disclosure are equally significant in the opinion of respondents. To identify key variables in companies practice/working influence their environmental disclosure multivariate regression analysis has been used with SPSS-19 software and results were shown in table 3 as under:

Table3: Multiple regression analysis* $\quad(\mathrm{N}=179)$

\begin{tabular}{|c|c|c|c|}
\hline Variable & SPSS Code & Mean & Std. Deviation \\
\hline IMPORTANCE & Importance & 2.3240 & 1.30515 \\
\hline Environment standalone reporting & Comp_ER_1 & 3.1508 & 1.14883 \\
\hline Environment Policy & Comp_ER_2 & 3.4190 & .89183 \\
\hline Membership of Environment Conserving & Comp_ER_3 & 3.5531 & .84881 \\
\hline Standard \& Guidelines of Environment & Comp_ER_4 & 2.5866 & 1.34792 \\
\hline Companies Environment Management System & Comp_ER_5 & 3.2793 & 1.17089 \\
\hline Environment and Social Risk Management & Comp_ER_6 & 2.6592 & 1.20908 \\
\hline Environment Accounting Audit & Comp_ER_7 & 3.3631 & 1.32266 \\
\hline Investments for conserving environment & Comp_ER_8 & 3.5978 & 1.22941 \\
\hline Total Cost for Conserving Environment & Comp_ER_9 & 3.0056 & 1.33449 \\
\hline Cost of Environment Performance Indicator & Comp_ER_10 & 3.4469 & .91874 \\
\hline Environment Cost savings & Comp_ER_11 & 3.6034 & .95646 \\
\hline Environment performance Indicator & Comp_ER_12 & 3.3687 & 1.03767 \\
\hline Emission Control & Comp_ER_13 & 3.2626 & 1.17717 \\
\hline Water usage & Comp_ER_14 & 3.3296 & 1.10044 \\
\hline Waste Management & Comp_ER_15 & 3.3520 & 1.25158 \\
\hline Product Stewardship & Comp_ER_16 & 3.5196 & .98495 \\
\hline Reduce, Recycle, Reuse & Comp_ER_17 & 3.5642 & .91802 \\
\hline Energy Saving & Comp_ER_18 & 3.8715 & .80743 \\
\hline Awards for environment Conservation & Comp_ER_19 & 3.6592 & .77970 \\
\hline Volatile Organic Compounds (VOC) & Comp_ER_20 & 3.7598 & 1.00188 \\
\hline Carbon Monoxide & Comp_ER_21 & 3.6145 & 1.06634 \\
\hline Hydro carbon & Comp_ER_22 & 3.5922 & 1.08418 \\
\hline Environmental Radiation Protection & Comp_ER_23 & 3.7207 & 1.07587 \\
\hline Environmental Noise Protection & Comp_ER_24 & 3.3240 & .96921 \\
\hline Green features of the building & Comp_ER_25 & 3.3296 & 1.14547 \\
\hline
\end{tabular}


International Advanced Research Journal in Science, Engineering and Technology

Impact Factor 7.105 Vol. 9, Issue 1, January 2022

DOI: 10.17148/IARJSET.2022.9156

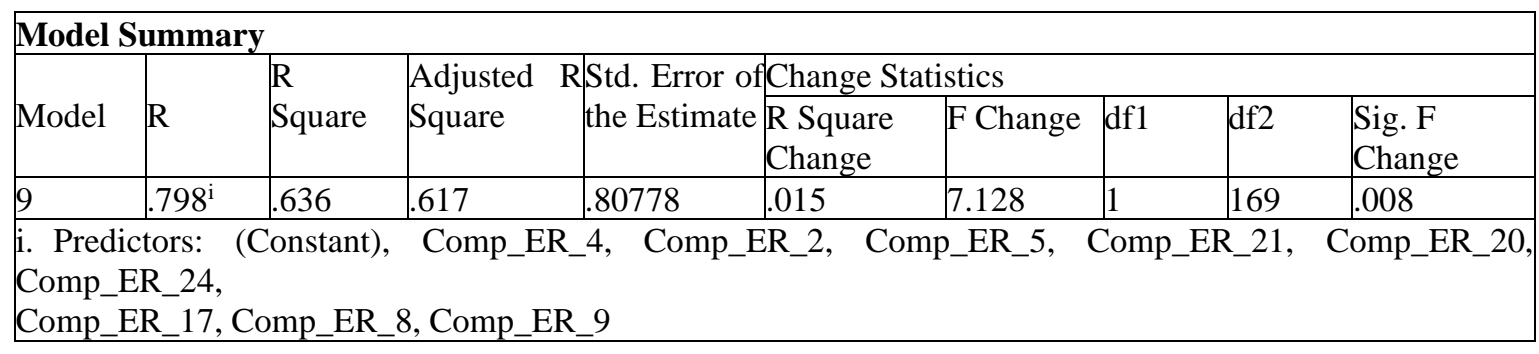

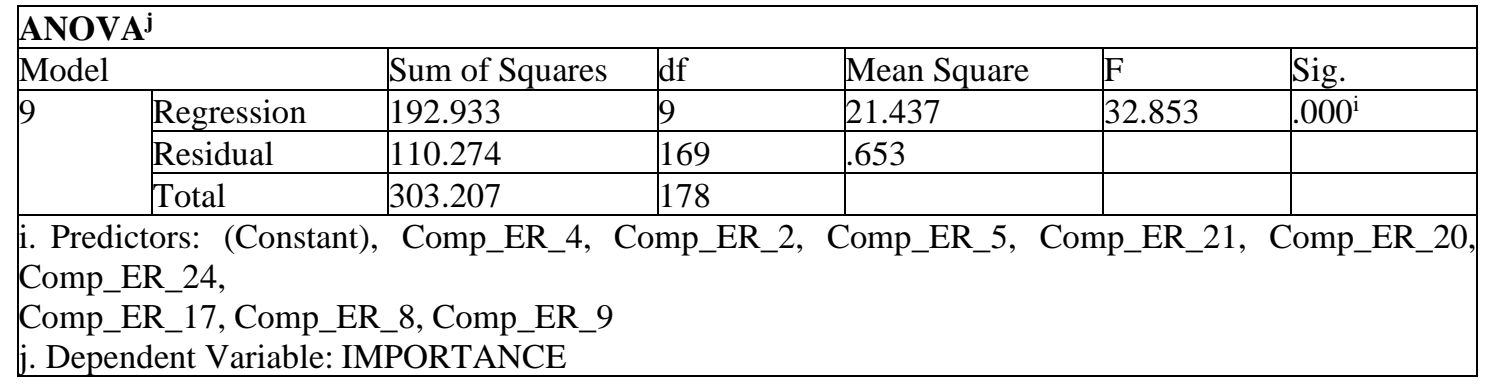

\begin{tabular}{|c|c|c|c|c|c|c|c|c|c|c|}
\hline \multicolumn{11}{|l|}{ Coefficients $^{\mathbf{a}}$} \\
\hline \multirow{3}{*}{ Model } & \multirow{2}{*}{\multicolumn{2}{|c|}{$\begin{array}{l}\text { Unstandardized } \\
\text { Coefficients }\end{array}$}} & \multirow{2}{*}{\begin{tabular}{|l|} 
Standar \\
dized \\
Coefficie \\
nts
\end{tabular}} & & \multirow{3}{*}{ Sig. } & \multicolumn{3}{|c|}{ Correlations } & \multicolumn{2}{|c|}{$\begin{array}{l}\text { Collinearity } \\
\text { Statistics }\end{array}$} \\
\hline & & & & & & \multirow{2}{*}{$\begin{array}{l}\text { Zero- } \\
\text { order }\end{array}$} & \multirow{2}{*}{ Partial } & \multirow{2}{*}{ Part } & \multirow{2}{*}{$\begin{array}{l}\text { Tole } \\
\text { rance }\end{array}$} & \multirow{2}{*}{ VIF } \\
\hline & B & $\begin{array}{l}\text { Std. } \\
\text { Error }\end{array}$ & Beta & & & & & & & \\
\hline \begin{tabular}{|l|l|}
9 & (Constant) \\
\end{tabular} & -1.029 & .394 & & -2.610 & .010 & & & & & \\
\hline Comp_ER_4 & .434 & .059 & .448 & 7.405 & .000 & .651 & .495 & .344 & .589 & 1.69 \\
\hline Comp_ER_2 & .293 & .079 & .200 & 3.698 & .000 & .428 & .274 & .172 & .736 & 1.35 \\
\hline Comp_ER_5 & .290 & .059 & .260 & 4.931 & .000 & .448 & .355 & .229 & .772 & 1.29 \\
\hline Comp_ER_21 & .350 & .073 & .286 & 4.826 & .000 & .236 & .348 & .224 & .612 & 1.63 \\
\hline Comp_ER_20 & -.143 & .069 & -.109 & -2.052 & .042 & -.03 & -.156 & -.095 & .757 & 1.32 \\
\hline Comp_ER_24 & .121 & .072 & .090 & 1.669 & .097 & .410 & .127 & .077 & .744 & 1.34 \\
\hline Comp_ER_17 & -.196 & .075 & -.138 & -2.610 & .010 & .250 & -.197 & -.121 & .770 & 1.29 \\
\hline Comp_ER_8 & -.174 & .058 & -.164 & -2.996 & .003 & .026 & -.225 & -.139 & .717 & 1.39 \\
\hline Comp_ER_9 & .158 & .059 & .161 & 2.670 & .008 & .457 & .201 & .124 & .590 & 1.69 \\
\hline
\end{tabular}

The final Regression model with 9 independent variables (Comp_ER_4, Comp_ER_2, Comp_ER_5, Comp_ER_21, Comp_ER_20, Comp_ER_24, Comp_ER_17, Comp_ER_8 and Comp_ER_9) explains almost 61.7\% of the variance of importance pertaining to companies practice/working. Also, the standard errors of the estimate have been reduced to 0.80778 . The 9 regression coefficients, plus the constraints are significant at 0.05 levels. The impact of multi colinerarity in the 9 variables is substantial. They all have the tolerance value less than 0.590 , indicating that over $40 \%$ of the variance is accounted for by the other variables in the equation.

\section{BENEFITS OF ENVIRONMENT ACCOUNTING \& REPORTING PRACTICES}

To find out the benefits of environment accounting and reporting by companies, the opinion of the respondents related to the comparative importance of these benefits. After identifying the major benefits the respondents were asked to rank them in the order of their importance.

Table 4: Ranks given for Benefits or ER $(\mathrm{N}=179)$

\begin{tabular}{|ll|l|l|l|l|l|l|l|}
\hline BENEFIT & & \multicolumn{3}{l|}{ SPSS code } & \multicolumn{2}{l|}{ Rank } & Average \\
\hline $\begin{array}{l}\text { Required for } \\
\text { sustainability }\end{array}$ & long term & Benefit_ER_1 & 13 & 27 & 34 & 81 & 24 & 3.4246 \\
\hline
\end{tabular}


International Advanced Research Journal in Science, Engineering and Technology

Impact Factor 7.105 Vol. 9, Issue 1, January 2022

DOI: 10.17148/IARJSET.2022.9156

\begin{tabular}{|l|l|l|l|l|l|l|l|}
\hline and sustainable future & & & & & & & \\
\hline $\begin{array}{l}\text { Improved image of the product or } \\
\text { company }\end{array}$ & & & & & & & \\
\hline Better accounting methods and data ER_2 & Benefit_ER_3 & 15 & 37 & 50 & 64 & 13 & 3.1285 \\
\hline Compare environment costs and benefits & Benefit_ER_4 & 24 & 29 & 39 & 70 & 17 & 3.1508 \\
\hline
\end{tabular}

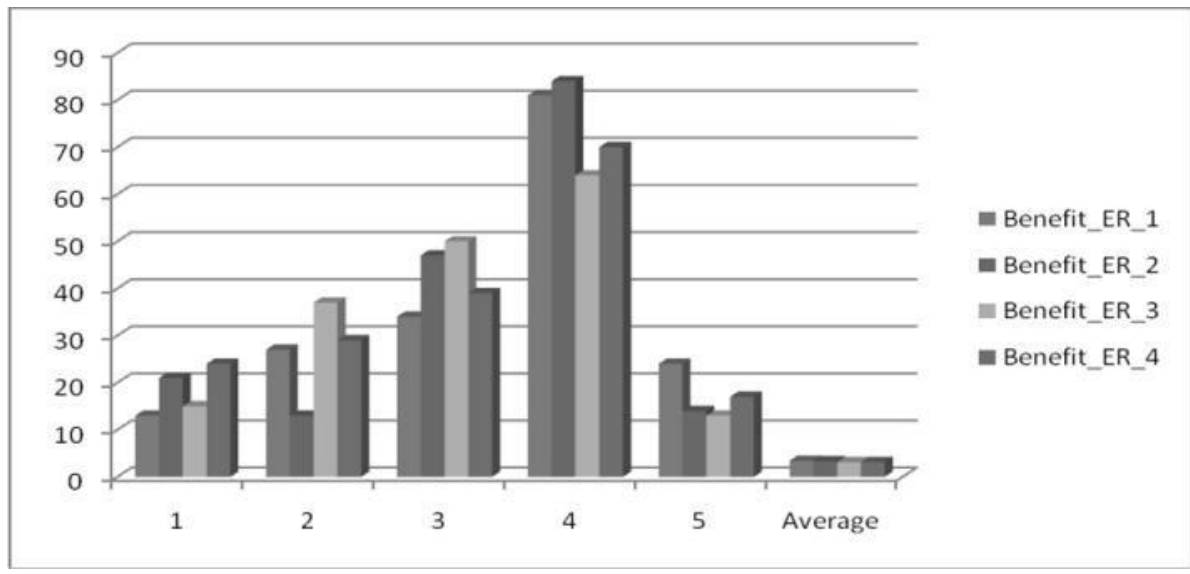

Figure 1: Rank given for Benefits or ER

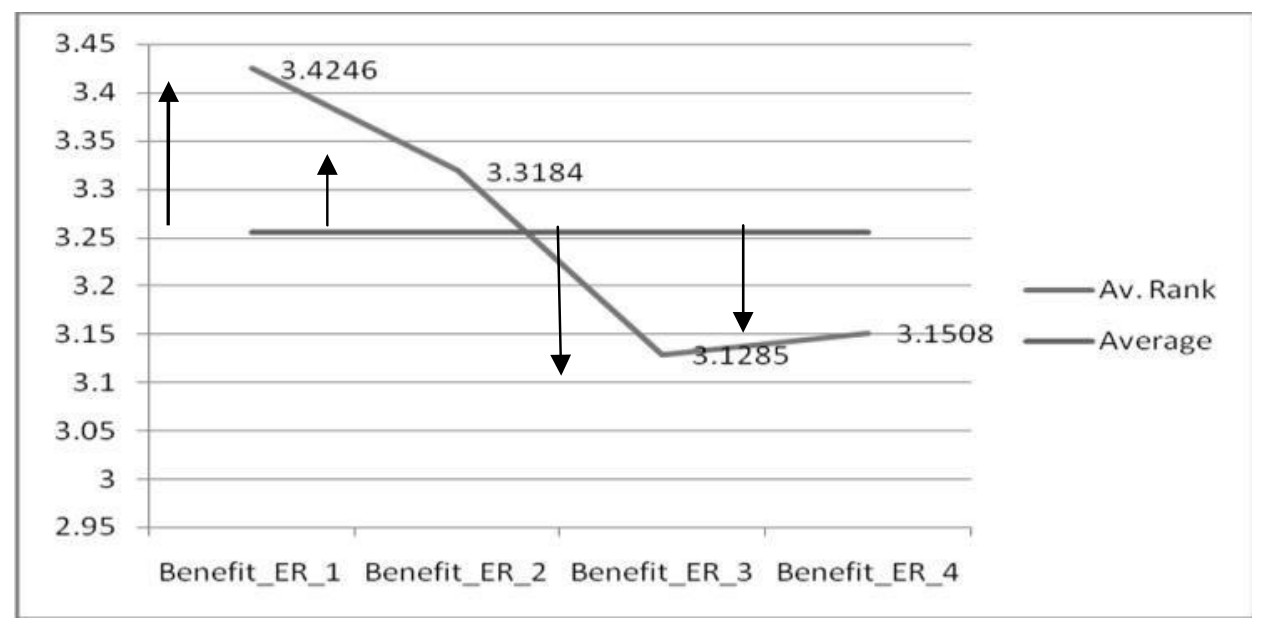

Figure 2: Differences from average and benefits or ER

Table 4 and figure 1 has shown the rank given by the respondents for Benefits or ER. Further figure 2 has shown that the hypothesis was rejected as variable Benefit_ER_1 and Benefit_ER_2 are given high ranks by the respondents.

\section{CONCLUSION}

The ANOVA analysis provides the statistical test for overall model fit in terms of F Ratio. The total sum of squares (303.207) is the squared error that would accrue if the mean of companiespractice/working been used to predict the dependent variable (Importance). Using the values of Comp_ER_4, Comp_ER_2, Comp_ER_5, Comp_ER_21, Comp_ER_20, Comp_ER_24, Comp_ER_17, Comp_ER_8 and Comp_ER_9 this error can be reduced by 63.63\% (192.933/303.207). This reductionis deemed statistically significant with the F ratio of 32.853 and significance at level of $0.000^{\mathrm{i}}$. With the above analysis it can be conclude that 9 variables i.e., Comp_ER_4, Comp_ER_2, Comp_ER_5, Comp_ER_21, Comp_ER_20, Comp_ER_24, Comp_ER_17, Comp_ER_8 and Comp_ER_9 explains the companies practice/working influence their environmental disclosure. Further as far as the benefits of the green accounting are concern, variable Benefit_ER_1 and Benefit_ER_2 are given high ranks by the respondents. 


\section{International Advanced Research Journal in Science, Engineering and Technology \\ Impact Factor 7.105 ㄷ Vol. 9, Issue 1, January 2022 \\ DOI: 10.17148/IARJSET.2022.9156 \\ REFERENCES}

- $\quad$ Andrew, J., \& Cortese, C. (2011). Accounting for climate change and the self-regulation of carbondisclosures. Accounting Forum, 35, 130-138.

- Dr. Neetu Prakash, "Environmental Accounting in India: A Survey of selected Indian Industries", Asian Research Consortium, Asian Journal of Research in Social Sciences and Humanities (2016), Vol. 6, No. 7, Pg. 1690-1705

- $\quad$ Dragomir, V.D. (2010). Environmentally sensitive disclosures and financial performance in a European setting. Journal of Accounting \& Organizational Change, 6(3), 359-388.

- $\quad$ Eugenio D’Amico, Daniela Coluccia, Stefano Fontana \& Silvia Solimene, "Factors Influencing Corporate Environmental Disclosure",Business Strategy \& Environment(2014).

- $\quad$ Gibson Nyirendra, Collins C. Ngwakwe and Cosmas M. Ambe, "Environmental Management Practices and Firm Performance in a South African Mining Firm" Managing Global Transitions (2013), Vol. 11, No. 3, Pg 243-260.

- Goswami,S. (2014). Environmental Reporting Practices among Select Industries in Rajasthan, Rajagiri Management Journal. 8(1), 29-45.

- Jones, Michael John. (2010). Accounting for the environment: Towards a theoretical perspective for environmental accounting and reporting. Accounting Forum, 34, 123-138, http://dx.doi.org/10.1016/j.accfor.2010.03.001

- $\quad$ Ljiljana Stankovic, Blagoje Novicevic and Suzana Dukic, "Designing Corporate Sustainability Performance Measurement System”, Facta Universtatis, Economics and Organization (2012), Vol.9, No.4, Pg 417-427.

- $\quad$ Markus J. Milne \& Rob Gray, "W(h)ither Ecology? The Triple Bottom Line, the Global Reporting Initiative, and Corporate Sustainability Reporting”, Springer, J Bus Ethics (2013), Vol. 118, Pg 13-29.

- Moneva, J.M., Ortas, E. (2010). Corporate environmental ms, 110(2), $193-210$. doi:10.1108/02635571011020304

- $\quad$ Muttanachai Suttipun \& Patricia Stanton, “A Study of Environmental Disclosures by Thai Listed Companies on Websites”, Elsevier Ltd, Procedia Economics \& Finance (2012), Vol. 2, Pg 9-15.

- $\quad$ Noor Raida Abd Rahman, Siti Zaleha Abdul Rasid, Rohaida Basiruddin, "Exploring the relationshipbetween carbon performance, carbon reporting and firm performance: A conceptual paper", Publisher Elsevier Ltd, Procedia Social and Behavioral Sciences (2014), Vol: 164, pg 118-125.

- $\quad$ R.C Dangwal and Preeti Sharma, “Environmental Disclosure Practices of Selected Indian Companies”,Journal of Accounting \& Finance(2014), Volume 28, No.2 pg 30-43

- $\quad$ Shavita Deshwal, "Green Accounting and Practices”, International Journal of Applied Research (2015), Vol. 1, No.8, Pg 683-684.

- Vidhani Jyoti and Shukla Anita (2018): Environmental Reporting in India: An Empirical Analysis, InspiraJournal of Modern Management \& Entrepreneurship (JMME). Volume 08, No. 02, April. pp. 299-306. ISSN : 2231$167 \mathrm{X}$

- Zhifang Zhou, Jing Ou \& Shihui Li, "Ecological Accounting: A Research Review and Conceptual Framework", Scientific Research Publishing, Journal of Environmental Protection (2016), Vol. 7, pg.643-655 